\title{
PENERAPAN MODEL PEMBELAJARAN PROBLEM-BASED LEARNING UNTUK MENINGKATKAN PEMAHAMAN KONSEP DAN MOTIVASI BELAJAR
}

\author{
Ika Widya Martanti \\ Prodi Pendidikan Akuntansi Universitas Negeri Yogyakarta \\ ikawidyamarta@gmail.com \\ Denies Priantinah \\ Jurusan Pendidikan Akuntansi Universitas Negeri Yogyakarta
}

\begin{abstract}
Abstrak
Penelitian ini merupakan Penelitian Tindakan Kelas yang bertujuan untuk meningkatkan Pemahaman Konsep dan Motivasi Belajar Akuntansi dengan menerapkan Model Pembelajaran Problem Based Learning. Penelitian ini dilaksanakan secara kolaboratif dan partisipatif selama dua siklus. Pengumpulan data dengan menggunakan tes tertulis, angket, lembar observasi, dan catatan lapangan. Analisis data yang digunakan adalah analisis kualitatif dan kuantitatif. Selain itu, peningkatan Pemahaman Konsep dan Motivasi Belajar Akuntansi juga dianalisis dengan uji Paired Samples T-test. Berdasarkan hasil penelitian disimpulkan bahwa penerapan Model Pembelajaran Problem Based Learning dapat meningkatkan Pemahaman Konsep dan Motivasi Belajar Akuntansi. Peningkatan Pemahaman Konsep Akuntansi ditunjukkan dengan peningkatan dari nilai pre-test ke posttest tiap siklusnya. Nilai rata-rata akhir siklus II sebesar 90,30 atau dalam kriteria sangat baik. Motivasi Belajar Akuntansi juga mengalami peningkatan antara skor sebelum dan setelah penerapan tiap siklusnya. Akhir siklus II skor rata-rata Motivasi Belajar berada pada kriteria baik sebesar 84,82 .
\end{abstract}

Kata kunci: Pemahaman Konsep, Motivasi Belajar, Problem Based Learning

\begin{abstract}
This study is a Classroom Action Research that aims to improve Understanding of Accounting Learning Concept and Accounting Learning Motivation by applying Problem Based Learning Model.This study was conducted in a collaborativeand participative way during two cycles. Data collection was conducted by using written tests, questionnaires, observation sheets, and field notes. Analysis of the data used was the qualitative and quantitative analysis.In addition, improving theUnderstanding of Accounting Learning Concept and Accounting Learning Motivation was also analyzed by Paired Samples T-test. Based on the result of the study, it is concluded that the implementation of Problem Based Learning Model can improve the Understanding of Accounting Learning Concept and Accounting Learning Motivation. The increase of the Understanding of Accounting Learning Concept is shown by the increase of the pre-test to post-testvalue in each cycle. The average value of the end of the second cycle is 90.30 or in a very well criteria. Accounting Learning Motivation is also increased which is shown by the difference of the scores before and after the application of each cycle. The average score of Learning Motivation in the end of the cycle IIis in a good criteria which is 84.82 .
\end{abstract}


Keywords: Understanding of Learning Concept, Learning Motivation, Problem Based Learning

\section{PENDAHULUAN}

Abad ke 21 merupakan era globalisasi dimana pengetahuan dan teknologi berkembang dengan sangat pesat. Pada era ini, menuntut Sumber Daya Manusia (SDM) yang berkualitas tinggi sehingga dapat bersaing di dunia global. Sadar akan tingginya tuntutan SDM, maka sistem serta model pendidikan nasional pun mengalami transformasi. Hal itu selaras dengan tujuan Pendidikan Nasional abad ke 21 adalah untuk mewujudkan citacita bangsa, yaitu masyarakat bangsa Indonesia yang sejahtera dan bahagia, dengan kedudukan yang terhormat dan setara dengan bangsa lain dalam dunia global (BSNP, 2010: 39).

Namun, Model pembelajaran yang berlangsung selama ini masih didominasi oleh teacher centered, artinya guru masih bersifat sebagai sumber pengetahuan sedangkan siswa bersifat pasif. Siswa lebih didoktrin untuk mendengarkan, menerima dan menghafal pengetahuan dari guru. Hal tersebut mengakibatkan kurangnya pemahaman siswa terhadap suatu konsep. Rendahnya pemahaman konsep yang dimiliki siswa akan berpengaruh pada hasil belajar yang diperoleh. Hasil belajar menentukan kualitas lulusan atau produk pendidikan yang diciptakan.

Untuk memperbaiki kualitas produk pendidikan, model pendidikan di abad 21 mengalami perubahan paradigma pada proses penyelenggaraan kegiatan pendidikan dan pembelajaran di dalam kelas atau lingkungan sekitar lembaga pendidikan tempat siswa menimba ilmu. Paradigma dalam proses pembelajaran dewasa ini adalah terciptanya pembelajaran yang bernuansa demokratis, dimana guru dan siswa belajar saling membantu.

Kurikulum pendidikan yang berlangsung saat ini berorientasi pada apa yang dilakukan siswa, bukan apa yang dapat dilakukan oleh guru. Orientasi dalam pembelajaran ini, siswa berperan lebih aktif dalam menemukan dan membangun informasi/ pengetahuannya, sedangkan guru akan lebih berfungsi sebagai fasilitator, pelatih, dan pendamping para siswa yang sedang mengalami proses pembelajaran. Dengan demikian, pelaksanaan pembelajaran memberikan kesempatan siswa untuk melakukan proses berpikir. 
Proses berpikir dalam pembelajaran, siswa diminta untuk mengkonstruksi pengetahuannya sendiri dengan memberdayakan kemampuan otak sehingga pengetahuan yang diperoleh siswa akan dipahami lebih mendalam. Pemahaman konsep suatu pengetahuan memang sangat penting, Santrock (2008: 351) mengatakan bahwa "Pemahaman konseptual adalah aspek kunci dari pembelajaran. Salah satu tujuan pengajaran yang penting adalah membantu murid memahami konsep utama dalam subjek materi pelajaran bukan sekedar mengingat fakta-fakta terpisah.” Berdasarkan pernyataan tersebut menunjukkan pentingnya pemahaman konsep dalam kegiatan pembelajaran karena pemahaman (understanding) dapat menjadi suatu landasan bagi peserta didik untuk membangun wawasan agar pembelajaran berlangsung lebih mudah dan merasakan kebermaknaan belajar.

Salah satu mata pelajaran yang memerlukan pemahaman konsep yang baik sehingga mendukung proses berpikir siswa Sekolah Menengah Atas (SMA) adalah Akuntansi. Proses berpikir pada pembelajaran ini berguna agar siswa dapat mengembangkan pemahaman konsepnya untuk menjadi individu yang cerdas, kreatif, kritis serta mampu mengaplikasikan ilmu untuk memecahkan permasalahan berkaitan dengan kehidupan sehari-hari.

Proses pembelajaran dengan mengutamakan kemampuan berpikir siswa juga diyakini akan meningkatkan motivasi belajar siswa. Motivasi merupakan daya penggerak siswa untuk belajar yang berasal dari luar atau dalam individu. Selaras dengan pendapat Hamzah B. Uno (2008: 34) yang menjelaskan bahwa motivasi dalam pembelajaran dapat ditingkatkan dengan teknik menimbulkan rasa ingin tahu. Proses berpikir merupakan solusi terbaik untuk memecahkan rasa ingin tahu siswa. Hal yang perlu diperhatikan oleh guru adalah pada saat yang sama tidak semua siswa secara intuitif dan intrinsik termotivasi untuk belajar, sehingga menjadi tugas guru untuk memotivasi beberapa siswa tersebut.

Hasil wawancara dan observasi awal yang dilakukan oleh peneliti di kelas XI IPS 1 dan 3 SMA Negeri 1 Pengasih pada tanggal 12 November 2013 menunjukkan ada permasalahan yang timbul dalam Kegiatan Belajar Mengajar (KBM) Akuntansi. Menurut guru Akuntansi yang mengampu kelas XI IPS, Motivasi Belajar Akuntansi siswa masih rendah. Beliau memaparkan tidak lebih dari 5 siswa saja tiap kelasnya yang mempunyai Motivasi Belajar Akuntansi tinggi. 
Pendapat tersebut didukung dengan tingkah laku siswa dalam mengikuti pembelajaran Akuntansi di kelas. Saat masuk pelajaran Akuntansi sekitar 60\% siswa belum menyiapkan buku dan perlengkapan Akuntansi sehingga guru harus menunggu siswa menyiapkan terlebih dahulu sebelum memulai pelajaran. Lebih dari $50 \%$ siswa tidak menyelesaikan Pekerjaan Rumah (PR) yang ditugaskan guru dengan berbagai alasan seperti lupa, banyak tugas dari pelajaran lain, dan berhenti mengerjakan karena menemukan soal yang sulit. Pada saat guru menjelaskan materi beberapa siswa mulai bosan, ditunjukkan dengan bersikap tak acuh, mengobrol dengan siswa lain, mengantuk, menopang dagu dan bermain ponsel. Setelah penjelasan, guru memberikan tugas kepada siswa namun beberapa siswa mengeluh dan malas mengerjakan. Guru harus mendatangi tiap meja siswa dan menanyakan kesulitan yang dialami terlebih dahulu barulah siswa mau mengerjakan. Sekitar $40 \%$ siswa tidak yakin dengan jawabannya sendiri sehingga siswa selalu mencocokkan jawaban dengan temannya bahkan beberapa diantaranya langsung menyontek jawaban teman. Pada 20 menit akhir pelajaran siswa yang masih mengerjakan tugas dengan serius hanya sekitar 5-6 siswa. Beberapa siswa yang diwawancarai juga mengemukakan bahwa pelajaran Akuntansi membosankan karena tugas yang diberikan guru dirasa kurang bervariasi, beberapa siswa bahkan merasa Akuntansi sulit dan membingungkan karena kurang memahami manfaat Akuntansi sehingga siswa kurang tertarik mengerjakan soal-soal Akuntansi.

Ditinjau dari metode pembelajaran yang diterapkan guru ternyata masih didominasipembelajaran konvensional berupa metode ceramah-resitasi. Setelah masuk kelas, guru menyampaikan materi pelajaran lalu diikuti dengan pemberian tugas atau latihan soal. Proses pembelajaran seperti ini belum memberikan kesan mendalam pada siswa. Pada metode konvensional seperti ini, guru lebih banyak memberikan penjelasan daripada mencari tahu seberapa jauh penerimaan dan pemahaman informasi atau konsep belajar yang disampaikan.

Hal ini terlihat saat siswa diminta menyelesaikan tugas Siklus Akuntansi Perusahaan Jasa sampai Neraca Saldo banyak siswa yang merasa kebingungan tetapi siswa yang bertanya hanya $20 \%$ atau sekitar 5-6 siswa. Sampai akhir jam pelajaran Akuntansi, masih belum ada siswayang selesai mengerjakan dan akhirnya tugas di kelas tersebut menjadi Pekerjaan Rumah (PR). Pemahaman konsep yang kurang diyakini menjadi 
penyebab rendahnya prestasi belajar yang diperoleh siswa, terbukti lebih dari50\% siswa tiap kelasnya belum memenuhi Kriteria Ketuntasan Minimal (KKM) sebesar 76. Oleh karena itu, cara yang bisa dilakukanoleh guru melihat fenomena di atas adalah menciptakan pembelajaran yang efektif. Pembelajaran efektif akan berlangsung apabila siswa terlibat aktif mengembangkan keterampilan berpikirnya dalam tugas-tugas yang bermakna.

Berpegang pada prinsip pada paradigma abad 21 yang menyatakan bahwa individu mempunyai keunikan dan talenta masing-masing, maka model pembelajaran yang dikembangkan adalah model pembelajaran yang memberikan kesempatan siswa untuk mengembangkan potensi dirinya. Salah satu model pembelajaran yang mengembangkan potensi diri siswa dengan memacu keterlibatan aktif siswa melalui proses berpikir yaitu Model Pembelajaran Problem Based Learning (PBL). Barrow (dalam Miftahul Huda, 2013: 271) mendefinisikan Pembelajaran Berbasis Masalah sebagai "pembelajaran yang diperoleh melalui proses menuju pemahaman akan resolusi suatu masalah. Masalah tersebut dipertemukan pertamatama dalam proses pembelajaran".

Keefektifan model pembelajaran ini adalah peserta didik lebih aktif dalam berpikir dan memahami materi secara berkelompok dengan melakukan investigasi terhadap permasalahan di sekitarnya sehingga mereka mendapatkan kesan yang mendalam dan lebih bermakna tentang apa yang mereka pelajari. Model ini cocok pada materi pelajaran Akuntansi karena pada mata pelajaran ini menuntut siswa untuk memiliki keterampilan pencatatan berdasarkan konsep-konsep yang dipelajari, dimana penguasaan keterampilan itu dilatih secara bertahap.

Agus Suprijono (2013: 73-74) memaparkan sintak pembelajaranProblem Based Learning (PBL) mencakup 5 fase dan perilaku diantaranya adalahsebagai berikut: Fase pertama guru memberikan orientasi permasalahan kepada peserta didik. Selanjutnya guru membantu peserta didik mengorganisasikan tugas belajar terkait dengan permasalahannya. Pada fase ketiga guru mendorong peserta didik melakukan investigasi mandiri dan kelompok untuk mencari penjelasan serta solusi. Tahap berikutnya guru membantu peserta didik dalam merencanakan dan menyiapkan hasil serta membantu mereka menyampaikannya kepada orang lain. Pada proses terakhir guru akan membantu peseta didik dalam menganalisis dan mengevaluasi dari proses mengatasi masalah yang mereka gunakan. 


\section{METODE}

\section{Desain Penelitian}

Penelitian yang digunakan dalam penelitian ini adalah Penelitian Tindakan Kelas (PTK) yang dilakukan secara kolaboratif dan partisipatif, artinya penelitian ini tidak dilakukan sendiri, tetapi bekerja sama dengan guru pelajaran Akuntansi kelas XI IPS SMA Negeri 1 Pengasih. Prosedur Penelitian Tindakan Kelas menggunakan model yang dikembangkan Kemmis dan Taggart, dilaksanakan sebanyak 2 siklus.

\section{Subjek dan Objek Penelitian}

Subjek penelitian ini adalah seluruh siswa kelas XI IPS 1 dan 3 SMA Negeri 1 Pengasih. Populasi kelas XI IPS 1 hanya terdiri dari 26 siswa dan kelas XI IPS 3 terdiri dari 25 siswa. Objek penelitian ini adalah Penerapan Model Pembelajaran Problem Based Learning pada pokok Jurnal Penyesuaian untuk Meningkatkan Pemahaman Konsep dan Motivasi Belajar Akuntansi Siswa Kelas XI IPS SMA Negeri 1 Pengasih Tahun Ajaran 2013/2014.

\section{Prosedur Penelitian}

Penelitian ini akan dilaksanakan dalam dua siklus dengan masing-masing siklus terdiri dari empat tahapan, yaitu tahap perencanaan tindakan, pelaksanaan tindakan, pengamatan dan refleksi.

Tahap perencanaan tindakan pada siklus I terdiri dari kegiatan menyusun RPP, merancang materi pembelajaran, menyusun LKS siklus 1 dan 2, soal pretest dan post-test siklus 1, lembar observasi, angket serta catatan lapangan. Setelah perencanaan matang, maka tahap selanjutnya yaitu pelaksanaan tindakan dengan berpedoman pada RPP. Pada tahap ini guru berperan sebagai tenaga pengajar sedangkan peneliti melakukan penelitian terhadap segala kegiatan guru dan siswa selama proses pembelajaran.Tahap ketiga yaitu pengamatan/observasi yang dilakukan saat pembelajaran berlangsung, sehingga tahap ini berjalan bersamaan dengan tahap pelaksanaan. Pengamatan dilakukan oleh peneliti dengan bantuan observer. Tahap terakhir adalah reflesi yang bertujuan untuk mengkaji secara menyeluruh tindakan yang telah dilakukan. Pada tahap ini dilakukan evaluasi untuk selanjutnya digunakan sebagai acuan tindakan kelas pada siklus selanjutnya.

Pada siklus II kegiatan yang dilakukan hampir sama dengan siklus I, tetapi perencanaan pada siklus II merupakan perbaikan terhadap kekurangan yang terjadi pada siklus I berdasarkan refleksi yang telah dilakukan. 


\section{Teknik Pengumpulan Data dan} Instrumen Penelitian

Data yang dikumpulkan dalam penelitian ini diperoleh dengan cara sebagai berikut: observasi, teknik evaluasi/ tes tertulis, angket, dokumentasi dan catatan lapangan. Adapun instrumen yang digunakan dalam penelitian ini adalah pedoman observasi, tes tertulis, LKS, angket dan catatan lapangan.

Pedoman observasi digunakan untuk pedoman observasi keterlaksanaan Model Pembelajaran Problem Based Learning. Penilaian dilakukan dengan mengamati aktivitas pembelajaran Akuntansi yang dilakukan oleh guru dan siswa di kelas sesuai dengan aspek yang tercantum pedoman observasi.

Tes berguna untuk mengukur kemampuan Pemahaman Konsep Akuntansi siswa dalam menyelesaikan suatu permasalahan. Tes berupa soal uraian disusun dengan berpedoman pada indikator untuk mengungkap kemampuan pemahaman konsep Akuntansi siswa. Soal tes berupapre-test dan post-test mencakup 2 siklus secara keseluruhan.

LKS berisi rumusan masalah yang berupa pertanyaan maupun studi kasus yang mengarahkan siswa ke konsep Jurnal Penyesuaian. LKS digunakan untuk memperoleh data tentang kemampuan
Pemahaman Konsep Akuntansi siswa secara kelompok.

Angket pada penelitian ini digunakan untuk mengukur Motivasi Belajar Akuntansi siswa sebelum dan setelah diterapkan Model Pembelajaran Problem Based Learning pada setiap siklus. Angket yang digunakan adalah jenis angket tertutup dengan bentuk rating scale berupa skala likert dengan tingkat jawaban dari selalu sampai tidak pernah.

Catatan lapangandigunakan untuk memperkuat data yang diperoleh dari lembar observasi pembelajaran. Hal-hal yang dicatat dalam catatan lapangan antara lain: suasana kelas, pengelolaan kelas, interaksi guru dengan siswa, interaksi siswa dengan siswa, dan segala sesuatu yang terjadi selama pembelajaran berlangsung dan tidak dapat tercatat dalam lembar observasi.

\section{Teknik Analisis Data}

Teknik analisis data yang digunakan dalam penelitian ini adalah teknik analisis data kualitatif dan kuantitatif. Teknik analisis data kualitatif terdiri dari dua langkah yaitu penyajian data yang berupa teks naratif dan penarikan kesimpulan.

Teknik analisis kuantitatif digunakan untuk mengetahui skor Pemahaman Konsep dan Motivasi Belajar 
Akuntansi siswa. Untuk menganalisis data secara kuantitatif dilakukan langkahlangkah sebagai berikut:

a. Analisis Pemahaman Konsep Akuntansi

1) Pemahaman Konsep tiap siswa

a) Menentukan kriteria pemberian skor terhadap masing-masing indikator.

b) Menjumlahkan skor untuk aspek Pemahaman Konsep Akuntansi.

c) Menghitung skor Pemahaman Konsep Akuntansi dengan rumus:

$\%=\frac{\text { Jumlahskor }}{\text { Jumlahskormaksimal }} \times 100 \%$ (Ngalim Purwanto, 2001: 102)

2) Pemahaman Konsep rata-rata kelas dengan rumus:

$\%=\frac{\text { Jumlah } \text { skor } \text { seluruhsiswa }}{\text { Jumlahsiswa }} \times 100 \%$

(Sugiyono, 2010: 49)

3) Uji perbedaan Pemahaman Konsep siklus I dan II menggunakan uji Paired Samples $T$ Test dan uji Normalitas sebagai uji prasyarat.

b. Analisis Motivasi Belajar Akuntansi

1) Motivasi Belajar tiap siswa

a) Menentukan kriteria pemberian skor terhadap masing-masing indikator.

b) Menjumlahkan skor untuk aspek Motivasi Belajar Akuntansi. c) Menghitung skor Motivasi Belajar Akuntansi dengan rumus:

$$
\%=\frac{\text { Jumlahskor }}{\text { Jumlahskormaksimal }} X 100 \%
$$

(Ngalim Purwanto, 2001: 102)

2) Motivasi Belajar rata-rata kelas dengan rumus:

$\%=\frac{\text { Jumlah skor seluruhsiswa }}{\text { Jumlahsiswa }} \times 100 \%$

(Sugiyono, 2010: 49)

3) Uji perbedaan Motivasi Belajar siklus I dan II dengan uji Paired Samples T Test dan uji Normalitas sebagai uji prasyarat.

Selanjutnya persentase tersebut dikategorikan sesuai dengan kualifikasi hasil persentase. Kriteria penilaian ditunjukkan pada tabel dan merupakan rujukan dari pendapat Ngalim Purwanto (2001: 103).

\section{Indikator Keberhasilan}

Menurut Mulyasa (2006: 101) pembelajaran dikatakan berhasil dan berkualitas dapat dilihat dari segi proses dan segi hasil. Dari segi proses, apabila sebagian besar $(75 \%)$ peserta didik terlibat aktif baik secara fisik, mental, maupun sosial dalam proses pembelajaran. 
Sedangkan dari segi hasil, apabila terjadi perubahan perilaku positif pada sebagian besar $(75 \%)$ diri peserta didik. Kriteria keberhasilan penelitian ini adalah adanya peningkatan Pemahaman Konsep dan Motivasi Belajar siswa dari siklus I ke siklus berikutnya.

a. Penilaian keberhasilan individu

1) Pemahaman Konsep siswa mengalami peningkatan nilai dari pre-test ke post-test dan minimal $75 \%$ dari jumlah siswa mencapai KKM yaitu 76 pada nilai post-test.

2) Motivasi Belajar siswa mengalami peningkatan dari skor Motivasi Belajar sebelum penerapan ke skor Motivasi Belajar setelah penerapan dan minimal $75 \%$ dari jumlah siswa telah mencapai ketuntasan dengan nilai > 75 (nilai KKM).

b. Penilaian keberhasilan secara keseluruhan apabila persentase Pemahaman Konsep dan Motivasi Belajar siswa minimal berada pada kriteria penilaian baik yaitu $76-85 \%$.

Tabel 1. Tabel Skala Persentase Penilaian

\begin{tabular}{cc}
\hline $\begin{array}{c}\text { Persentase } \\
\text { Penilaian }\end{array}$ & Interpretasi \\
\hline$<54 \%$ & Kurang sekali
\end{tabular}

$\begin{array}{cc}55-59 \% & \text { Kurang } \\ 60-75 \% & \text { Cukup } \\ 76-85 \% & \text { Baik } \\ 86-100 \% & \text { Sangat baik }\end{array}$

HASIL DAN PEMBAHASAN

Keterlaksanaan

Problem-Based

\section{Learning}

Hasil pengamatan pembelajaran pada Siklus I, seluruh indikator keterlaksanaan $P B L$ telah terlaksana. Namun ada kekurangan pada siklus I yang diperbaiki pada siklus II seperti memotivasi siswa bekerja secara kelompok, membimbing dalam penyelesaian kasus dengan berkeliling memantau diskusi serta aktif mengarahkan presentasi berjalan dengan tepat waktu, meningkatkan partisipasi aktif siswa dengan mewajibkan setiap kelompok menyampaikan tanggapan/pendapat.

\section{Pemahaman Konsep Akuntansi}

Pada aspek Pemahaman Konsep Akuntansi peningkatan diukur dengan nilai pre-test dan post-test pada siklus I dan II. Tabel 2 menunjukkan perbandingan persentase Pemahaman Konsep antara Siklus I dan II.

Pada pre-test siklus I jumlah siswa tuntas ada 5 siswa dengan persentase $10 \%$, jumlah siswa tuntas meningkat menjadi 26 siswa atau sebesar $52 \%$ saat post-test siklus I dilakukan. Dilihat dari nilai rata- 
rata saat post-test siklus I mencapai nilai 73,30 dengan kriteria cukup.

Pada saat siklus II, nilai pre-test siswa yang tuntas sebanyak 24 siswa atau $36 \%$. Siswa yang tuntas saat post-test siklus II menjadi 47 siswa atau sebesar 94\%. Data tersebut menunjukkan ada peningkatan dari nilai pre-test ke post-test secara klasikal. Nilai rata-rata juga mengalami peningkatan pada siklus II menjadi 90,30. Nilai tersebut telah masuk dalam kategori sangat baik artinya data telah melampaui kriteria minimal.

Tabel 2. Perbandingan Persentase Pemahaman Konsep

\begin{tabular}{|c|c|c|}
\hline \multirow{4}{*}{ Nilai } & \multicolumn{2}{|c|}{ Jumlah Siswa } \\
\hline & Siklus I & Siklus II \\
\hline & Post- & Post- \\
\hline & test test & test \\
\hline
\end{tabular}

Kelas XI IPS 1 :

$\begin{array}{lcccc}\text { Tuntas } & 3 & 13 & 10 & 25 \\ \text { Tidak Tuntas } & 23 & 13 & 16 & 1 \\ \text { Jumlah Siswa } & 26 & 26 & 26 & 26\end{array}$

Kelas XI IPS 3 :

$\begin{array}{lllll}\text { Tuntas }(\geq 76) & 2 & 13 & 8 & 22\end{array}$

$\begin{array}{lllll}\text { Tidak Tuntas } & 22 & 11 & 16 & 2\end{array}$

\begin{tabular}{lcccc} 
Jumlah Siswa & 24 & 24 & 24 & 24 \\
Jumlah Siswa & 5 & 26 & 18 & 47 \\
$\begin{array}{l}\text { Tuntas } \\
\text { Rata-rata }\end{array}$ & 53,1 & 73,3 & 71,5 & 90,3 \\
Nilai & & & & \\
Persentase & $10 \%$ & $52 \%$ & $36 \%$ & $94 \%$ \\
Ketuntasan & & & & \\
Peningkatan & \multicolumn{2}{c}{$42 \%$} & \multicolumn{2}{c}{$58 \%$} \\
\hline
\end{tabular}

Sumber: Data primer yang diolah

Peneliti selanjutnya melakukan uji Paired Samples T Test. Nilai t hitung pada siklus Isebesar -15,715 dan -18.327 pada siklus II sedangkan nilai t tabelsebesar 2.010. Karena -t hitung < - t tabel maka $\mathrm{H}_{0}$ ditolak, artinya ada pengaruh yang signifikan pada Pemahaman Konsep antara sebelum dan setelah penerapan.

Dari data pada tabel 2 juga menunjukkan persentase peningkatan dari nilai pre-test ke post-test pada masingmasing siklus. Nilai peningkatan pada siklus I adalah $42 \%$, sedangkan pada siklus II adalah 58\%. Data tersebut memperlihatkan nilai peningkatan pada siklus II jauh lebih tinggi daripada siklus I sehingga diyakini apabila Model Pembelajaran Problem Based Learning secara berkelanjutan oleh guru maka akan diperoleh hasil Pemahaman Konsep yang semakin baik.

\section{Motivasi Belajar Akuntansi}


Hasil Motivasi Belajar diukur dengan skor angket pada tiap siklus yang dibagikan sebelum dan setelah tindakan. Peningkatan dinilai dari skor setelah tindakan dibandingkan dengan skor sebelum tindakan pada siklus I dan II.

Pada data sebelum tindakan siklus I jumlah siswa yang memenuhi kriteria minimal sebanyak 9 siswa atau $18 \%$. Jumlah siswa tuntas naik menjadi 31 siswa atau sebesar $62 \%$ setelah penerapan. Ditinjau dari skor rata-rata juga mengalami kenaikan dari 65,05 dengan kriteria cukup menjadi 76,37 dengan kriteria baik.

Pada siklus II siswa telah memenuhi kriteria minimal sebelum tindakan sejumlah 17 siswa. Jumlah tersebut meningkat pada skor angket sesudah penerapan menjadi 46 siswa atau sebesar 92\%. Skor rata-rata Motivasi Belajar juga mengalami kenaikan menjadi 84,82 dengan kategori baik. Untuk lebih jelas, tabel 3 menyajikan hasil perbandingan persentase Motivasi Belajar siklus I dan II.

Uji Paired Samples T Test yang dilakukan peneliti menunjukkan nilai $\mathrm{t}$ hitung -22.498 pada siklus I dan 26.611pada siklus II sedangkan nilai $\mathrm{t}$ tabelsebesar -2.010. Karena $-\mathrm{t}$ hitung $<-\mathrm{t}$ tabel maka $\mathrm{H}_{0}$ ditolak, artinya penerapan Model Pembelajaran Problem Based
Learning berpengaruh yang signifikan pada Motivasi Belajar Akuntansi.

Dari data di atas juga menunjukkan presentase peningkatan pada skor sebelum ke setelah tindakan pada siklus I dan siklus II. Siklus I menunjukkan peningkatan sebesar $11,32 \%$, sedangkan pada siklus II sebesar $11,98 \%$. Presentase peningkatan pada siklus II lebih tinggi daripada siklus I, hal tersebut menunjukkan jika penerapan Model Pembelajaran Problem Based Learning dilakukan secara berkelanjutan oleh guru dalam pembelajaran Akuntansi maka akan diperoleh hasil Motivasi Belajar Akuntansi yang semakin baik.

Tabel 3. Perbandingan Persentase Motivasi Belajar

\begin{tabular}{lcccc}
\hline & \multicolumn{4}{c}{ Jumlah Siswa } \\
\multicolumn{1}{c}{ Nilai } & \multicolumn{2}{c}{ Siklus I } & \multicolumn{2}{c}{ Siklus II } \\
& Sebe & Sesu & Sebe & Sesu \\
& lum & dah & lum & dah \\
\hline Kelas XI IPS 1: & & & \\
Tuntas & 5 & 16 & 9 & 24 \\
Tidak Tuntas & 21 & 10 & 17 & 2 \\
Jumlah & 26 & 26 & 26 & 26
\end{tabular}


Siswa

Kelas XI IPS 3 :

$\begin{array}{lcccc}\text { Tuntas } & 4 & 15 & 8 & 22 \\ \text { Tidak Tuntas } & 20 & 9 & 16 & 2 \\ \text { Jumlah } & 24 & 24 & 24 & 24\end{array}$

Siswa

Jumlah

$\begin{array}{llll}9 & 31 & 17 & 46\end{array}$

Siswa Tuntas

Rata-rata $\quad 65,0 \quad 76,3 \quad 72,8 \quad 84,8$

$\begin{array}{lllll}\text { Skor } & 5 & 7 & 4 & 2\end{array}$

Persentase $\quad 18 \% \quad 62 \% \quad 34 \% \quad 92 \%$

Ketuntasan

Peningkatan

$11.32 \%$

$11.98 \%$

Sumber: Data yang diolah

\section{SIMPULAN DAN SARAN}

\section{Simpulan}

Berdasarkan hasil penelitian dan pembahasan maka dapat disimpulkan bahwa Model Pembelajaran Problem Based Learning dapat meningkatkan Pemahaman Konsep dan Motivasi Belajar Akuntansi siswa Kelas XI IPS SMA Negeri 1 Pengasih. Proses pembelajaran Akuntansi dengan Model Pembelajaran Problem Based Learning juga telah berjalan sesuai sintaks pembelajaran. Seluruh kelemahan pada siklus I telah berhasil diperbaiki pada siklus II.

Peningkatan Pemahaman Konsep yang dimiliki siswa XI IPS 1 dan 3 dilihat dari perbandingan nilai pre-test keposttest. Persentase peningkatan nilai
Pemahaman Konsep pada siklus I adalah $42 \%$ menjadi $58 \%$ pada siklus II. Nilai rata-rata siswa akhir siklus II sebesar 90,30 dengan kriteria sangat baik. Nilai tersebut telah melampaui kriteria yang ditetapkan (76-85). Uji Paired Samples T-test menunjukkan ada pengaruh signifikan antara sebelum dan setelah penerapan sehingga mendukung hasil siklus I dan II.

Untuk peningkatan Motivasi Belajar diukur dari skor angket sebelum dan sesudah tindakan. Persentase peningkatan skor Motivasi Belajar pada siklus I sebesar $11,32 \%$ meningkat menjadi $11,98 \%$ pada siklus II. Nilai ratarata yang diperoleh akhir siklus II juga mencapai skor 84,82 dengan kriteria baik. Nilai tersebut telah memenuhi kriteria minimal (76-85). Berdasarkan uji Paired Samples T-test juga menunjukkan terdapat pengaruh signifikan antara sebelum dan setelah penerapan.

\section{Saran}

Penelitian ini memberikan beberapa saran sebagai berikut:

1. Bagi Guru

a. Guru dapat menerapkan Model Pembelajaran Problem Based Learning dengan kondisi siswa yang memiliki Pemahaman Konsep dan Motivasi Belajar rendah. Model 
Pembelajaran ini mengutamakan partisipasi aktif siswa dan peran guru dalam membimbing dan mendampingi siswa.

b. Kerjasama saling membantu antara guru dan siswa penting untuk diperhatikan sehingga pembelajaran berlangsung lebih efektif.

\section{Bagi Siswa}

a. Siswa harus membiasakan untuk bekerjasama secara kelompok.

b. Siswa sebaiknya menumbuhkan motivasi belajar mereka sendiri, terutama motivasi belajar internal yaitu motivasi dari dalam diri mereka.

c. Siswa sebaiknya berpartisipasi aktif di kelas, jangan takut berpendapat, menanggapi, atau menyanggah.

3. Bagi Penelitian Selanjutnya

a. Peneliti dapat memperluas penilaian pada aspek-aspek lain dari Pemahaman Konsep.

b. Pada aspek Motivasi Belajar, peneliti dapat melakukan cara pengambilan data tidak hanya menggunakan angket tetapi diikuti dengan observasi.

\section{DAFTAR PUSTAKA}

Agus Suprijono. (2013). Cooperatif Learning: Teori dan Aplikasi PAIKEM. Yogyakarta: Pustaka Pelajar.

BSNP. (2010). Paradigma Pendidikan nasional Abad XXI. Diakses tanggal 7 Oktober 2013. dari http://www.4shared.com/office/Vq7j hS4m/PARADIGMA_PENDIDIKA N_NASIONAL_html.

E. Mulyasa. (2006). Kurikulum Berbasis Kompetensi Konsep, Karakteristik, Implementasi dan Inovasi. Bandung: Remaja Rosdakarya.

Hamzah B. Uno. (2008). Teori Motivasi dan Pengukurannya: Analisis di Bidang Penelitian. Jakarta: Bumi Aksara.

Miftahul Huda. (2013). Model-model Pengajaran dan Pembelajaran: Isuisu Metodis dan Paradigmatis. Yogyakarta: Pustaka Pelajar.

Ngalim Purwanto. (2001). Prinsip-prinsip dan Teknik Evaluasi Pengajaran. Bandung: Remaja Rosdakarya.

Santrock, W. Jhon. (2008). Psikologi Pendidikan Edisi Kedua (Alih bahasa: Tribowo B.S). Jakarta: Prenada Media Group.

Sugiyono. (2010). Statistika Untuk Penelitian. Bandung: Alfabeta. 